\title{
PERINATAL LESSONS FROM THE PAST
}

\section{George Armstrong MD (1719-1789) and his Dispensary for the Infant Poor}

\section{P M Dunn}

George Armstrong published one of the first textbooks on children's diseases in 1767 and two years later opened in London the first dispensary/hospital in the world for sick children. He introduced clinical teaching and may be regarded as the founder of paediatrics and child health in Great Britain.

Correspondence to:

Professor Dunn

Department of 'Child

Health, University of Bristol,

Southmead Hospital,

Southmead, Bristol BS10 5

NB, UK;

P.M.Dunn@Bristol.ac.uk

Accepted 2 May 2002

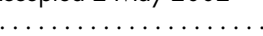

Arch Dis Child Fetal Neonatal Ed 2002;87:F228-F231

to infants (fig 2). ${ }^{3}$ This text, which cost $2 \mathrm{~s} 6 \mathrm{~d}$, marked the conversion of paediatrics from a conjectural art into a branch of scientific medicine. Extended editions were published in 1771, 1777, and $1783 .{ }^{4}$ They were widely acclaimed on the continent as well as in the United Kingdom.

At that time the London bills of mortality revealed that between a quarter and a half of all infants died within a year of birth. Armstrong discussed the reasons in his book:

\section{On the past neglect of children's diseases ${ }^{4}$}

"If we take a survey of the different provinces of medicine, we shall readily discover, that one that happens to be of the greatest consequence to society, as the population of every country in great measure depends upon it, I mean that which regards the diseases of infants, has hitherto lain uncultivated, or at least been much neglected. I do not pretend to account for this strong neglect, nor is it to my purpose: but certain it is, that though the human species can only be preserved

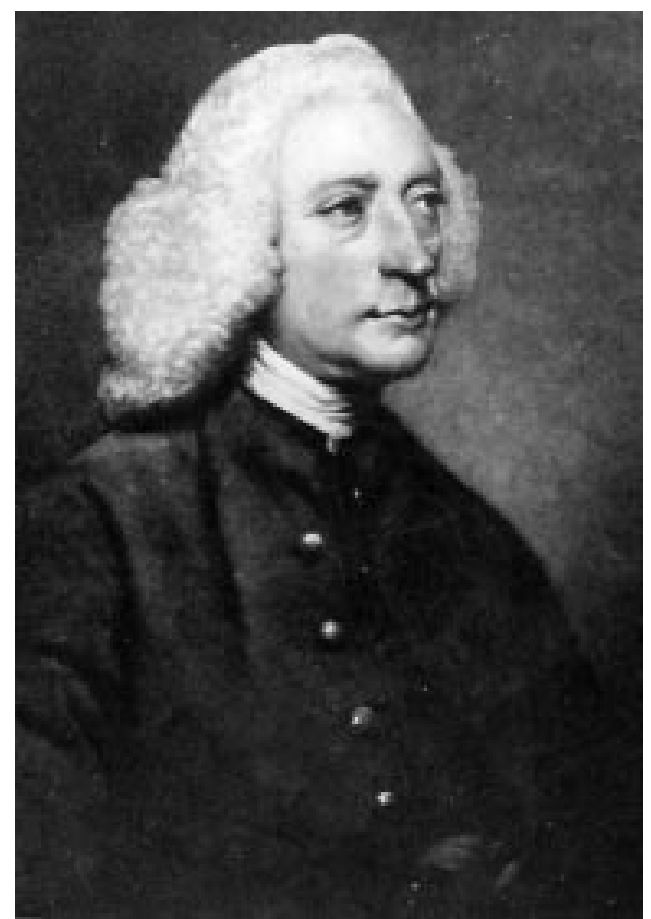

Figure 1 John Armstrong (1709-1779), George's elder brother. 


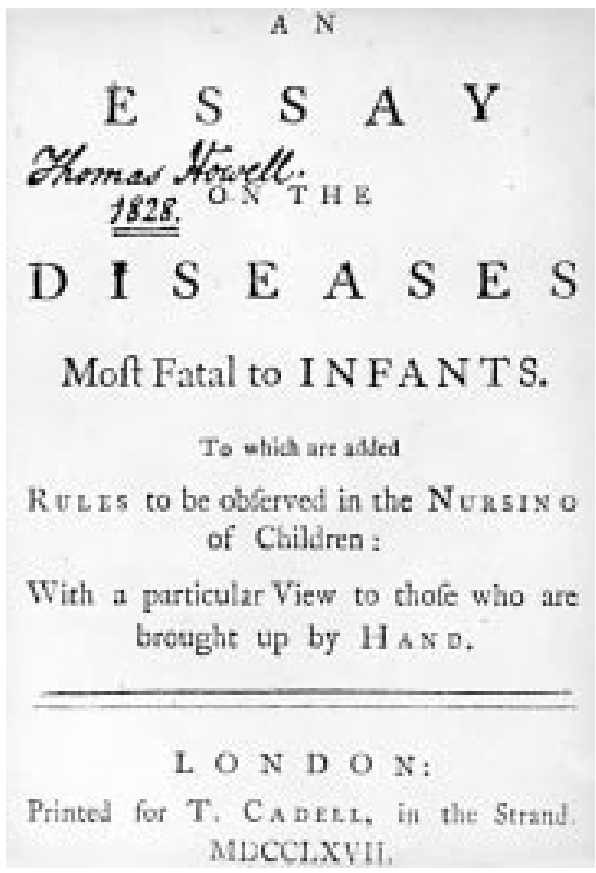

Figure 2 Frontispiece to George Armstrong's text of 1769.

by taking proper care of the infant race, which is much more helpless than the young of other animals; and though a much great number of our species in proportion to the whole, than any other that we know, dies very young; yet the care of infants, even with regard to medicine, has commonly been left to old women, nurses, and midwives, so that it has long been a common saying in this country, that the best doctor for a child, is an old woman .... I know there are some of the physical tribe who are not fond of practicing among infants; and having heard an eminent physician say, that he never wished to be called in to a young child; because he was really at a loss to know what to order for it. Nay, I am told, there are physicians of note here, who make no scruple to assert, that there is nothing to be done for children when they are ill . . .. The most plausible excuse for declining to practice amongst infants is, that they are not capable of telling their ailments; therefore, say, some, it is working in the dark, and while you endeavour to relieve them, perhaps you may do them a mischief, instead of a service. . . But though infants are not capable of expressing their complaints by words, the very symptoms themselves will, for the most part, speak for them, in so plain a manner as to be easily understood ..... These circumstances I mention, chiefly to convince parents and others who, from a false notion that there is little or nothing to be done for infants when they are ill, defer calling in proper assistance till it is too late .. .. But there is still another reason why children are sometimes neglected . . .. it is this: children, while in their infancy, especially if the young family is numerous, and the parents in straightened circumstances, are not thought of sufficient consequence to be much attended to ...."

Armstrong's text dealt with many children's diseases including thrush, watery gripes, convulsions, hydrocephalus, teething, hectic fever, intertrigo, measles, smallpox, eye problems, rickets, worms, scrofula, and hooping cough. He kept careful records as this example of audit demonstrates: "From the time of the first institution of the Dispensary for the Infant Poor, which was on April 24th, 1769, till the beginning of June 1777, I had seven hundred and thirty-two poor children, ill of the Hooping-Cough, under my care; out of which number have died twenty-five." ${ }^{4} \mathrm{He}$ also undertook postmortem examinations to determine the cause of death as this famous example shows:

\section{On pyloric stenosis}

"In a child of about three weeks old that died of watery gripes and which I opened some time since, I found most of the stomach towards the upper orifice and almost the whole fundus in the same tender state but towards the pylorus the structure was firm enough as likewise that of the intestine both small and great. The stomach was quite distended with curdled milk and victuals with which the nurse had crammed the child, mixed likewise with some of the child's julep, but the whole intestines were remarkably empty. There were no morbid appearances to be observed anywhere but in the stomach and this viscus being so full while the intestines were almost empty, it looked as if the disease had been chiefly owing to a spasm in the pylorus, which prevented the contents of the stomach from passing into the duodenum. Perhaps cases of this kind are more frequent than is commonly imagined . . .. What is remarkable this is the third child (and they never had any more) which the parents have lost at the same age and with the same disease. And this was likewise the case in the family where the other died."

Armstrong not only pioneered modern paediatrics but also emphasised the importance of child health and the prevention of disease, as did also his contemporaries, William Cadogan and William Buchan. The following extracts reveal his approach:

\section{On keeping infants warm ${ }^{4}$}

"... too great care cannot be taken to prevent the child's getting cold in the birth. This, I am induced to believe, is a much more frequent source of diseases and death amongst infants, especially in the lower class of people, than is generally imagined. . . Considering the sudden transition which a child makes from the mother's womb, to the air, even of a warm room, one would wonder that any should escape getting cold in the birth, especially in cold weather, if great care is not taken to cover their tender bodies properly with something warm as soon as they are born; but everybody knows, that too many of the poorer sort of women here, have but very cold, miserable apartments to be delivered in, except those who are admitted into the lying-in hospitals. This may be one principal reason, why a greater number of the children of the poor here die in their infancy, than of the rich, as I have elsewhere remarked. Sometimes, after a hard labour, the midwife and other assistants are so much occupied about the mother . . . that the poor infant is for a while neglected. The keeping of infants warm, so as to preserve them from catching cold during the first few months is of so much consequence with regard to their future health and thriving, that the greatest care should be taken in this point."

Armstrong was a strong supporter of breast feeding for the mother's sake (to prevent milk fever) as well as for the 


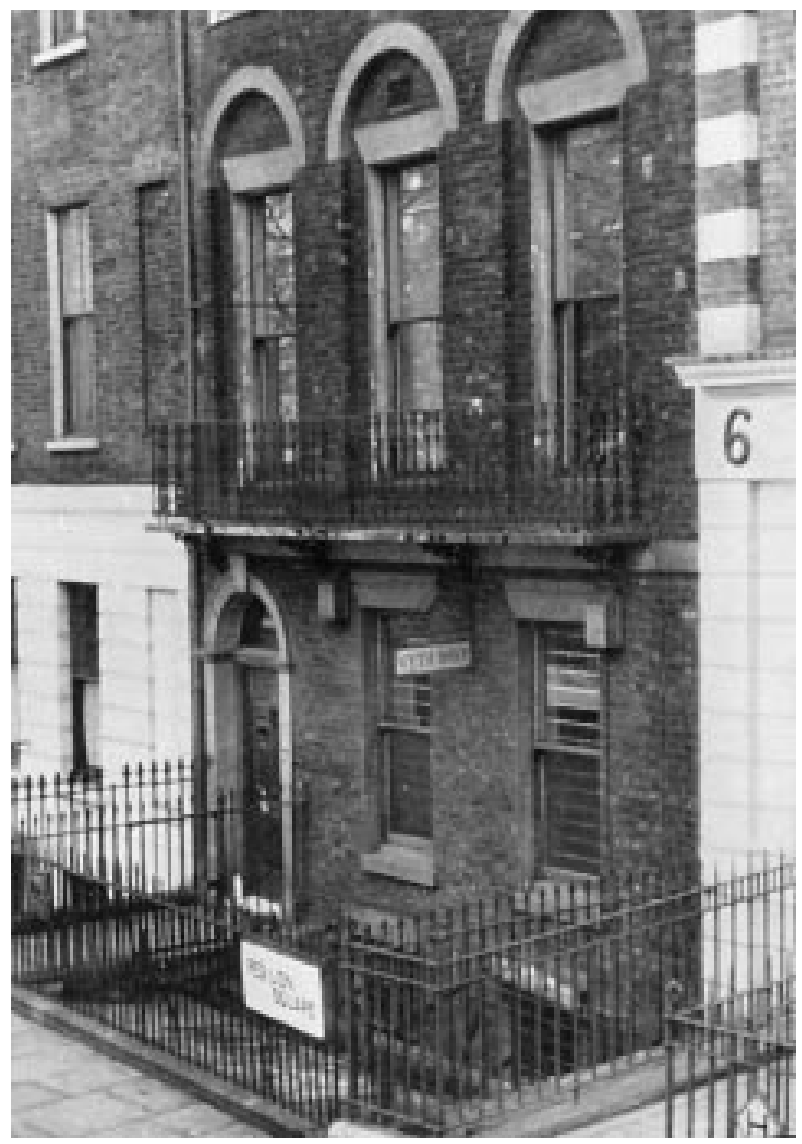

Figure 3 The Dispensary for the Infant Poor, 7 Red Lion Square, London, 1769.

infant's. When infants had to be fed by hand, he argued a preference for a boat or spoon, rather than a horn. Clothing should be loose with as few pins as possible. The importance of good hygiene was emphasised as was the need for sleep, exercise, and stimulation.

In 1769 Armstrong acquired the diploma of MD, probably from the University of Aberdeen, and with the support of seven Scottish physicians in London, including William Hunter, he opened a Dispensary for the Infant Poor at 7 Red Lion Square, a house owned by Dr John Munroe, FRCP ( fig 3). He was still unlicensed to practice in London but the College of Physicians gave their tacit approval by appointing three of their senior fellows to the management committee. Looking back some years later, Armstrong gave the following account of this, the first dispensary/hospital for children in the world:

\section{The Dispensary for the Infant Poor ${ }^{4}$}

"This is the only charity, as far as I know, that has ever been instituted solely for the relief of children. The design of it being to administer advice and medicines gratis to the children of the industrious poor, from birth till the age of ten or twelve years, and its salutary effects cannot be more evidently demonstrated, than from the great number of patients relieved by it. During a period of twelve years and nine months; i.e. from its first institution in April 1769, till December 1781, when, from want of health, I was no longer able to attend it, the number of infants relieved by this charity amounted to nearly thirty-five thousand, as appeared by the Dispensary Books . . .. Another advantage attending this charitable institution is, its being confined to children only, whereby their complaints are more closely attended to, and considered; for when sick children are admitted promiscuously with adults, the former never have so much attention paid them as the latter ... .. Besides, at this Dispensary a particular account is kept of all the children's cases, together with the method of treating them, which is not done at any of the other charities. A further circumstance in recommendation of this charity, in which it differs from all others, I cannot help mentioning, which is, that it receives children without any letters of admission, provided the parents are really indigent, the case dangerous, and requiring speedy relief ....

But, in conducting the physical department of the Dispensary, I did not confine myself to the therapeutic or curative part of the physic only; I likewise extended my care to the prophylactic branch, or that which concerns the prevention of diseases, constantly endeavouring to hinder their being so frequent, or so violent, when they happen . . .. Cleanliness amongst the parents, nurses, and children, I encourage and commend, both on account of its decency and its salutary effects; and whenever any of them has come dirty to the dispensary (which several used to do at first), I have constantly reproved them of it; in consequence of which it has seldom lately happened that any one came who was not clean and decently dressed....

It has been remarked by many of its friends, that no charitable institution was ever established, whereby so much good has been done, or so many lives saved at so small an expense, as by this very charity. And here I cannot help remarking, that, though this charity has been generally approved of and confessed to be the best calculated for promoting population, and therefore should be considered as a national object of singular importance, yet, unfortunately, it met with so little encouragement, that it all along lay a burden on the original institutor, as many of the principal guardians and subscribers to the Dispensary can testify. To finish this short account, I cannot help adding, that this being the first charitable institution of the kind, it may justly claim the merit of having given rise to all other charitable Dispensaries in the Kingdom."

Armstrong not only trained mothers in the proper care of their infants and children but also his fellow practitioners. As he wrote: "The Dispensary for the Infant Poor will be found of great service, as it affords a constant supply of a great number and variety of cases in almost all the diseases (the chronicall ones at least) to which the infant age is subject; and thereby becomes a continual fund of experience, which must be of the greatest use towards qualifying young beginners for practising among children (if they avail themselves of it)." His method of teaching paediatrics was widely adopted in England and abroad. Thus was the clinical instruction of paediatrics first introduced into medical practice.

The immediate success of the Dispensary and the increasing demands made on it led to a move to bigger premises, first in East Street later in 1769 and then to Soho Square in 1772, at which the whole family moved down from Hampstead. However, there were serious problems in funding. George, no doubt helped by his brother John who was a consulting physician to the Dispensary, was paying many of the expenses out of his own pocket. When John died following a fall in 1779, matters 
became critical. In 1780 George borrowed $£ 100$ from a crooked solicitor, Thomas Millington, on security for the title deeds of a wharf that he and his wife owned. Millington then almost at once demanded repayment and, when Armstrong was unable to do so, had him committed to a debtor's prison. Eventually the charge was dismissed and Armstrong was released in 1781. But later that year he had a stroke paralysing the left side of his body and had to give up work. His last effort was to re-edit the text of his book. As he wrote: "As soon as my health and strength would allow, I returned to my task; but continuing very weak, it went slowly on, and I found it a tiresome affair to finish". ${ }^{4}$ After the publication of the 1783 edition, ${ }^{4}$ Armstrong passes into obscurity until his death on 21 January 1789. He was then 69. There was no obituary and the name of this great pioneer was almost entirely forgotten. But not quite. In 1808 A P Buchan, the son of William Buchan who had also been born in Roxburgh, re-edited Armstrong's text with many notes of his own. At the same time, Buchan accused Michael Underwood (and he was not alone in doing so) of plagiarising Armstrong's work in his own textbook first published in 1785.
Underwood's response was to disparage Armstrong's achievements. Meanwhile, some 80 years later, the Hospital for Sick Children in Great Ormond Street was perhaps mistakenly greeted in 1852 as the first British paediatric hospital.

In the present century, Armstrong has at last received due acclaim as the founder of the world's first dispensary/hospital for sick children, for pioneering in children's diseases and child health, for his teaching of clinical paediatrics, and for his regard for the social welfare of children. He has, with justification, been dubbed the true founder of modern paediatrics and child health in the United Kingdom. ${ }^{1}$

\section{REFERENCES}

1 Maloney WJ. George and John Armstrong of Castleton. Edinburgh: E \& S Livingstone, 1954.

2 Still GF. The history of paediatrics. Oxford: Oxford University Press, 1931.

3 Armstrong G. An essay on the diseases most fatal to infants. London: T Cadell, 1767

4 Armstrong G. An account of the diseases most incident to children, from birth to the age of puberty; with a successful method of treating them. 3rd ed. London: T Cadwell, 1783.

\section{This month in the Archives of Disease in Childhood}

The following papers appearing in the November 2002 issue of $A D C$ may be of interest to readers of Fetal and Neonatal.

Fat oxidation defect presenting with overwhelming ketonuria. E Wraige, M P Champion, $C$ Turner, $R$ N Dalton

- Commentary P J Galloway, P H Robinson

Pulsed dye laser for Sturge-Weber syndrome. C Léauté-Labrèze, F Boralevi, J-M Pedespan, Y Meymat, A Taïbe 